\title{
Species Complex of Fruit Flies, Bactrocera spp. (Diptera: Tephritidae) Infesting Guava in Western Uttar Pradesh, India
}

\author{
Irsad* and Masarrat Haseeb
}

Department of Plant Protection, Faculty of Agricultural Sciences, A.M.U., Aligarh, India

*Corresponding author

\begin{tabular}{|c|c|}
\hline & B S T R A C T \\
\hline $\begin{array}{l}\text { Fruit fly, Species } \\
\text { complex, } \\
\text { Proportionate } \\
\text { population, Guava }\end{array}$ & \multirow{3}{*}{$\begin{array}{l}\text { The species diversity of Dacinae fruit flies (Bactrocera spp.) was monitored in guava } \\
\text { growing areas in various districts of western Uttar Pradesh, India, over a } 12 \text { months period } \\
\text { (October, 2017- September, 2018). Samples of fruit flies were collected by using methyl } \\
\text { eugenol lure traps and infested guava fruits collected from the farmer's orchards in fruiting } \\
\text { season. Three species of fruit flies recorded were, Bactrocera correcta, B. dorsalis and } B \text {. } \\
\text { zonata. In general, proportionately higher population of B. zonata was recorded form } \\
\text { various places surveyed. There was not much difference in species composition in } \\
\text { different places. However, on an average, population differences were noticed in different } \\
\text { areas. Number of adult fly emergence from the infested guava fruits collected from } \\
\text { different places was proportionately in the range of } 21.00-69.85 \%, 21.06-49.80 \% \text { and } \\
20.12 \%-43.65 \% \text { for B. zonata, B. dorsalis and B. correcta, respectively. }\end{array}$} \\
\hline Article Info & \\
\hline $\begin{array}{l}\text { Accepted: } \\
\text { 22 July } 201 \\
\text { Available } 0 \\
10 \text { August }\end{array}$ & \\
\hline
\end{tabular}

\section{Introduction}

Guava is the fourth most important fruit (after mango, banana, and citrus), commercially cultivated in India with an estimated area of 261 thousand hectares and production of 3916 thousand MT (Anonymous 2017). Among the Indian states, Uttar Pradesh tops with the maximum cultivation of guava with an area of 99 thousand hectares and production of 919.94 thousand MT (Anonymous 2017). In India, particularly in Uttar Pradesh, guava suffers colossal losses due to infestation of fruit flies and is a major limiting factor among the insect pests infesting this crop (Kapoor,
2002; Rajitha and Viraktamath, 2006; Haseeb, 2007). Fruit flies are a regular pest in chief guava growing areas of Uttar Pradesh i.e. Allahabad, Kaushambi, Lucknow, Faizabad (Eastern and Central UP), Farrukhabad, Sasni, Sadabad, Badaun (Western UP). However, it has been observed that this crop suffers maximum in rainy season resulting in the heavy reduction in fruit production (Haseeb, 2007 and Haseeb, et al., 2010).

Fruit flies belonging to the family tephritidae are the most diversified group of insects and they are considered as significant and serious pests of horticultural crops the world over. A 
number of species of fruit flies gained entry in places other than its origin and have been recorded as alien species causing serious infestations and losses. It is a major pest of significance because of its polyphagous nature, cosmopolitan distribution, nature of the damage, resulting losses and quarantine status (Kapoor, 2006; Drew et al., 2007; Drew and Romig, 2013; Liu et al., 2013; Ukey et al., 2013). Among the tephritid fruit flies, sub family Dacinae possess maximum number of economically important species. The Dacinae is a large group of tephritid fruit flies, with over 800 described species, primarily within the genera Bactrocera and Dacus. Of these, about 60 are known to occur in India, mostly infesting edible host fruits and fleshy vegetables, resulting in fruit losses (Nair et al., 2018). Among the Dacinae fruit flies the genus Bactrocera is of significance as it contains economically important species, with particular reference to $B$. dorsalis, $B$. correcta, B. zonata, B. cucurbitae which have been reported to potentially infest more than 173 kinds of fruits and vegetables including mango, banana, peach, guava, citrus spp., apricot, rose apple, jujube, Chinese date, fig, sapodilla, cucurbits and other vegetables (Gupta \& Verma, 1978; White \& ElsonHarris, 1992; Allwood et al., 1999; Drew \& Raghu, 2002; Verghese et al., 2004; Dhillon et al., 2005; Ekesi et al., 2016).

Among fruits, guava is one of the highly susceptible fruit of commercial importance which is attacked by different species of fruit flies. The extent of damage/crop losses due to fruit flies have been recorded to vary between 16-40 per cent (Arora et al., 1998); 60-80 per cent (Jalaluddin et al., 1999); 10-80 per cent (Verghese et al., 2002); 20-46 per cent (Haseeb, 2007); few per cent -100 per cent (Kumar et al., 2011); up to 100 per cent (Mondal et al., 2015). In western Uttar Pradesh, Sasni (Hathras near Aligarh), the most important area, famous for guava cultivation has been found suffering from heavy infestation of fruit flies in rainy season guava and increasing population noticed in winter season too as indicated by the results of preliminary surveys (Haseeb et al., 2010). As the information on species complex of fruit flies was not available from this area, the present studies were undertaken to explore the fruit fly species complex, so that proper management strategies may be chalked out to control the pest in this area and in other areas of western UP.

\section{Materials and Methods}

\section{Study sites}

The present studies were carried out from October 2017 to September 2018 in guava orchards of districts, namely: Aligarh, Hathras, Bulandshahar, Agra, Firozabad, Mathura, Badaun and nearby areas in Western U. P., This study aimed to explore the fruit fly complex in guava in western Uttar Pradesh, mainly Sasni (Hathras), a chief guava growing area in the region. (Fig 1).

\section{Collection of specimens}

Fruit flies were collected by the following two methods:

Use of Para-pheromone traps: Fruit fly plastic traps with the transparent bowl and the yellow cap having an entry hole of $6 \mathrm{~cm}$ in diameter were used. These traps were purchased from Devine trap industries, Kolkata, West Bengal. Transparent water bottle traps were also prepared in the laboratory and installed in selected guava orchards. Liquid lures (Methyl eugenol) used in traps to attract fruit flies (males), were obtained from Apex Life Sciences, New Delhi. Traps baited with methyl-eugenol were installed in two orchards at each locality at a distance of 20 meters and 5 feet height above the ground. 
Flies were collected from the traps at the weekly interval and brought to the laboratory, observed under a binocular microscope for the identifications.

Rearing of flies from infested fruits: The infested guava (selected out of harvested and freshly fallen fruits), were collected from the orchards in fruiting season and brought to the laboratory. Such fruits were placed in rearing cages provided with sterilized sand at the bottom so as to facilitate pupation. The emerged fruit flies were provided with Protein hydrolysate, glucose and water soaked in a cotton swab for a week. In this way, flies were allowed to complete the process of sclerotization and development of colour so as to facilitate identification.

Data were also recorded on proportionate population of different fruit fly species reared from infested fruits brought to the laboratory from different places to know the relative distribution and abundance. Number of different species emerged out of infested guava fruits were counted and percentage out of the total flies emerged, was calculated. Data analysis was done by using Minitab software, 2018.

\section{Identification of specimens}

The collected flies were killed by using a killing agent (Ethyl acetate/Chloroform) and examined under a binocular microscope. The flies were identified to the species level. On the basis of morphological characters with the help of taxonomical keys (Source: Dr. C. A. Viraktamath and Dr. K. J. David, UAS, GKVK, Bangalore). The number of species at a particular locality was recorded. The fruit flies also got identified from Insect Identification Services, National Pusa Collection, Division of Entomology, IARI,
New Delhi. The specimens of fruit flies were also deposited in the National Pusa Collection at Pusa, IARI, New Delhi.

\section{Results and Discussion}

\section{Species of fruit flies caught in para- pheromone (methyl eugenol) traps}

As a result of present investigations, fruit fly species recorded in guava growing areas of western Uttar Pradesh are presented in Table1. Three species of fruit flies, viz. B. correcta, $B$. dorsalis, and B. zonata were recorded from various districts i.e. Hathras (Sasni, Samamai Ruhal), Aligarh, Agra, Bulandshahar, Badaun. However, only 2 species of fruit flies, viz. $B$. dorsalis and $B$. zonata were recorded from Chhatarpur locality in Hathras district and district Firozabad. In general, a proportionately higher population of $B$. zonata was recorded trapped to methyl eugenol traps followed by $B$. dorsalis and $B$. correcta.

\section{Species of fruit flies reared from infested guava fruits}

Species of fruit flies bred from guava fruits collected from different localities/districts were identified as B. correcta, B. dorsalis and $B$. zonata. All the three species were recorded from Hathras (Sasni, Samamai Ruhal), Aligarh, Agra, Bulandshahar, Badaun districts. Whereas, only 2 species viz., $B$. dorsalis and $B$. zonata were recorded from Hathras locality Chhatarpur, Mathura and Firozabad as indicated in the Table- 1.

Fruit fly (Bactrocera spp.) community structure and their distribution at different districts/ areas of western Uttar Pradesh are depicted in the Map (Fig. 1). 
Table.1 Species of fruit flies caught through ME traps and reared from infested guava fruits

\begin{tabular}{|c|c|c|c|c|c|}
\hline S. N. & District & Locality & $\begin{array}{l}\text { No. of } \\
\text { species }\end{array}$ & $\begin{array}{l}\text { Species of fruit flies } \\
\text { caught in para- } \\
\text { pheromone trap }\end{array}$ & $\begin{array}{l}\text { Species of fruit flies } \\
\text { reared from infested } \\
\text { guava fruits in } \\
\text { laboratory }\end{array}$ \\
\hline \multirow[t]{8}{*}{1.} & Hathras & Sasni & 03 & $\begin{array}{l}\text { Bactrocera correcta } \\
\text { (Bezzi) }\end{array}$ & $\begin{array}{l}\text { Bactrocera correcta } \\
\text { (Bezzi) }\end{array}$ \\
\hline & & & & $\begin{array}{l}\text { Bactrocera dorsalis } \\
\text { (Handel) }\end{array}$ & $\begin{array}{l}\text { Bactrocera dorsalis } \\
\text { (Handel) }\end{array}$ \\
\hline & & & & $\begin{array}{l}\text { Bactrocera zonata } \\
\text { (Saunders) }\end{array}$ & $\begin{array}{l}\text { Bactrocera zonata } \\
\text { (Saunders) }\end{array}$ \\
\hline & & $\begin{array}{l}\text { Samamai } \\
\text { Ruhal }\end{array}$ & 03 & Bactrocera correcta & Bactrocera correcta \\
\hline & & & & Bactrocera dorsalis & Bactrocera dorsalis \\
\hline & & & & Bactrocera zonata & Bactrocera zonata \\
\hline & & Chhatarpur & 02 & Bactrocera dorsalis & Bactrocera dorsalis \\
\hline & & & & Bactrocera zonata & Bactrocera zonata \\
\hline \multirow[t]{6}{*}{2.} & Aligarh & $\begin{array}{l}\text { Rajkiya } \\
\text { Jawahar } \\
\text { Udhyan }\end{array}$ & 03 & Bactrocera correcta & Bactrocera correcta \\
\hline & & & & Bactrocera dorsalis & Bactrocera dorsalis \\
\hline & & & & Bactrocera zonata & Bactrocera zonata \\
\hline & & $\begin{array}{l}\text { Botanical } \\
\text { garden }\end{array}$ & 03 & Bactrocera correcta & Bactrocera correcta \\
\hline & & & & Bactrocera dorsalis & Bactrocera dorsalis \\
\hline & & & & Bactrocera zonata & Bactrocera zonata \\
\hline \multirow[t]{2}{*}{3.} & Mathura & Koshi Khurd & 02 & & Bactrocera correcta \\
\hline & & & & & Bactrocera zonata \\
\hline \multirow[t]{3}{*}{4.} & Bulandshahar & Pandrawal & 03 & & Bactrocera zonata \\
\hline & & & & & Bactrocera correcta \\
\hline & & & & & Bactrocera dorsalis \\
\hline \multirow[t]{2}{*}{5.} & Firozabad & $\begin{array}{l}\text { Navalpur, } \\
\text { Eka }\end{array}$ & 02 & Bactrocera zonata & Bactrocera zonata \\
\hline & & & & Bactrocera dorsalis & Bactrocera dorsalis \\
\hline \multirow[t]{3}{*}{6.} & Agra & Bichpuri & 03 & Bactrocera correcta & Bactrocera correcta \\
\hline & & & & Bactrocera dorsalis & Bactrocera dorsalis \\
\hline & & & & Bactrocera zonata & Bactrocera zonata \\
\hline \multirow[t]{3}{*}{7.} & Badaun & Kakrala & 03 & Bactrocera correcta & Bactrocera correcta \\
\hline & & & & Bactrocera dorsalis & Bactrocera dorsalis \\
\hline & & & & Bactrocera zonata & Bactrocera zonata \\
\hline
\end{tabular}


Table.2 Proportionate population of different species of fruit flies, Bactrocera spp. as reared from infested guava fruits

\begin{tabular}{|c|c|c|c|c|c|}
\hline S. No. & District & Locality & $\begin{array}{l}\text { Species of fruit flies } \\
\text { reared from infested } \\
\text { guava fruits in } \\
\text { laboratory }\end{array}$ & Per-cent & Total \\
\hline \multirow[t]{8}{*}{1.} & Hathras & Sasni & Bactrocera correcta & 29.49 & \multirow[t]{3}{*}{556} \\
\hline & & & Bactrocera dorsalis & 30.75 & \\
\hline & & & Bactrocera zonata & 39.76 & \\
\hline & & $\begin{array}{l}\text { Samamai } \\
\text { Ruhal }\end{array}$ & Bactrocera correcta & 28.76 & \multirow[t]{3}{*}{518} \\
\hline & & & Bactrocera dorsalis & 31.08 & \\
\hline & & & Bactrocera zonata & 40.16 & \\
\hline & & Chhatarpur & Bactrocera dorsalis & 30.15 & \multirow[t]{2}{*}{322} \\
\hline & & & Bactrocera zonata & 69.85 & \\
\hline \multirow[t]{6}{*}{2.} & Aligarh & $\begin{array}{l}\text { Rajkiya } \\
\text { Jawahar } \\
\text { Udhyan }\end{array}$ & Bactrocera correcta & 29.20 & 440 \\
\hline & & & Bactrocera dorsalis & 49.80 & \\
\hline & & & Bactrocera zonata & 21.00 & \\
\hline & & $\begin{array}{l}\text { Botanical } \\
\text { garden }\end{array}$ & Bactrocera correcta & 24.36 & 612 \\
\hline & & & Bactrocera dorsalis & 36.92 & \\
\hline & & & Bactrocera zonata & 38.72 & \\
\hline \multirow[t]{2}{*}{3.} & Mathura & Koshi khurd & Bactrocera correcta & 43.65 & 380 \\
\hline & & & Bactrocera zonata & 56.35 & \\
\hline \multirow[t]{3}{*}{4.} & Bulandshahar & Pandrawal & Bactrocera zonata & 58.82 & 350 \\
\hline & & & Bactrocera correcta & 20.12 & \\
\hline & & & Bactrocera dorsalis & 21.06 & \\
\hline \multirow[t]{2}{*}{5.} & Firozabad & $\begin{array}{l}\text { Navalpur, } \\
\text { Eka }\end{array}$ & Bactrocera zonata & 68.82 & 330 \\
\hline & & & Bactrocera dorsalis & 31.18 & \\
\hline \multirow[t]{3}{*}{6.} & Agra & Bichpuri & Bactrocera correcta & 36.19 & 315 \\
\hline & & & Bactrocera dorsalis & 35.88 & \\
\hline & & & Bactrocera zonata & 27.93 & \\
\hline \multirow[t]{3}{*}{7.} & Badaun & Kakrala & Bactrocera correcta & 31.59 & 307 \\
\hline & & & Bactrocera dorsalis & 35.83 & \\
\hline & & & Bactrocera zonata & 32.57 & \\
\hline
\end{tabular}


Table.3 Mean population of different species at given locality

\begin{tabular}{|l|c|c|c|}
\hline Location & B. correcta (Mean) & B. dorsalis (Mean) & B. zonata (Mean) \\
\hline Sasni & 34.20 & 32.80 & 44.20 \\
\hline Samamai Ruhal & 32.20 & 29.80 & 41.60 \\
\hline Chhatarpur & 0.00 & 19.60 & 44.80 \\
\hline Rajkiya Jawahar Udhyan & 25.60 & 43.80 & 18.60 \\
\hline Botanical garden & 29.80 & 45.20 & 47.40 \\
\hline Mathura & 33.20 & 0.00 & 42.80 \\
\hline Firozabad & 0.00 & 20.60 & 45.40 \\
\hline Bichpuri & 22.80 & 22.60 & 17.60 \\
\hline Kakrala & 19.40 & 22.00 & 20.00 \\
\hline Bulandshahar & 14.00 & 14.80 & 41.20 \\
\hline & $L S D 9.19$ & $L S D 10.58$ & $L S D 13.278$ \\
& $F 17.36$ & $F 15.66$ & $F 11.02$ \\
\hline & $P<0.005$ & $P<0.005$ & $P<0.005$ \\
\hline
\end{tabular}

Fig.1 Sampling site and distribution of fruit fly community are indicating by different colours in map

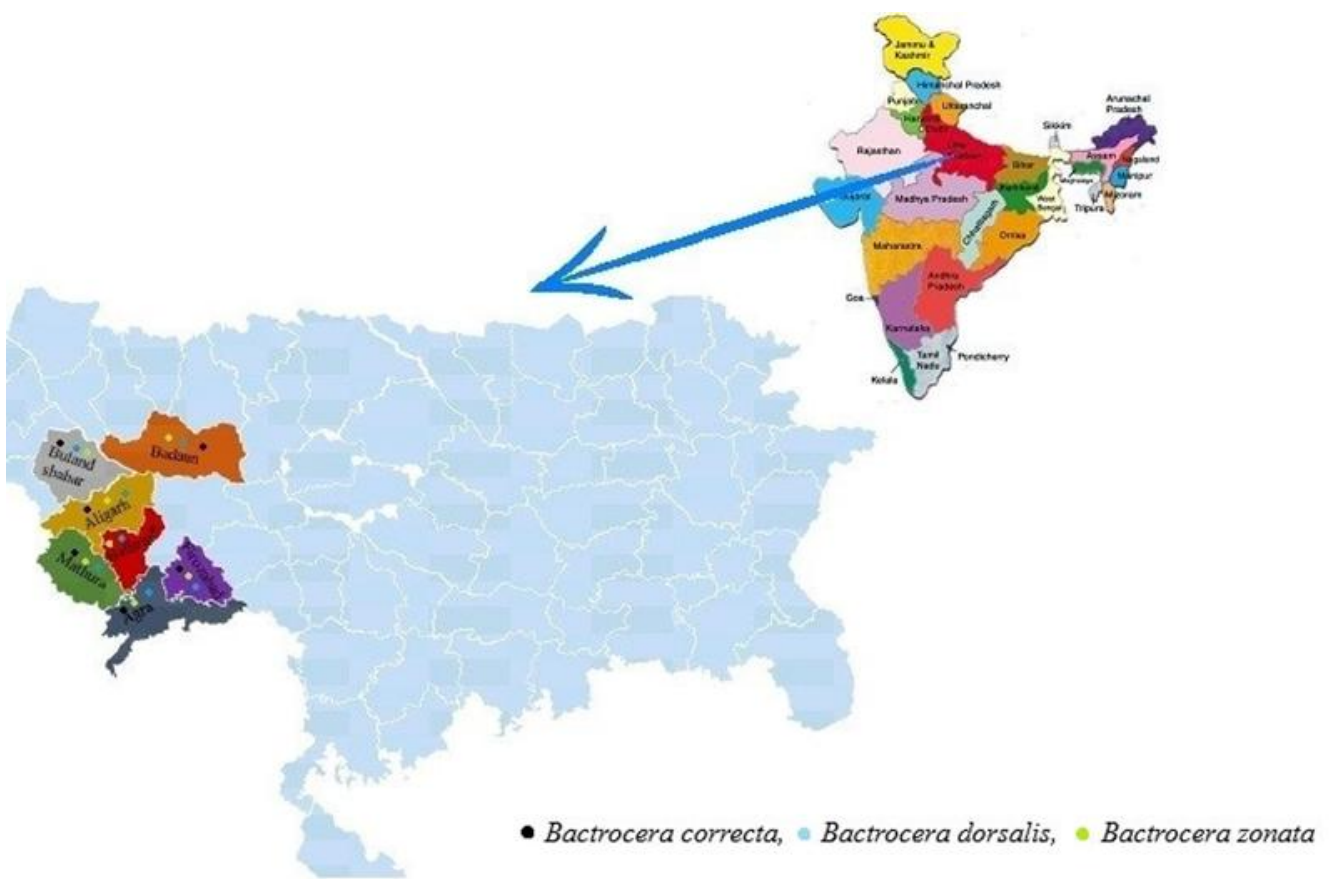




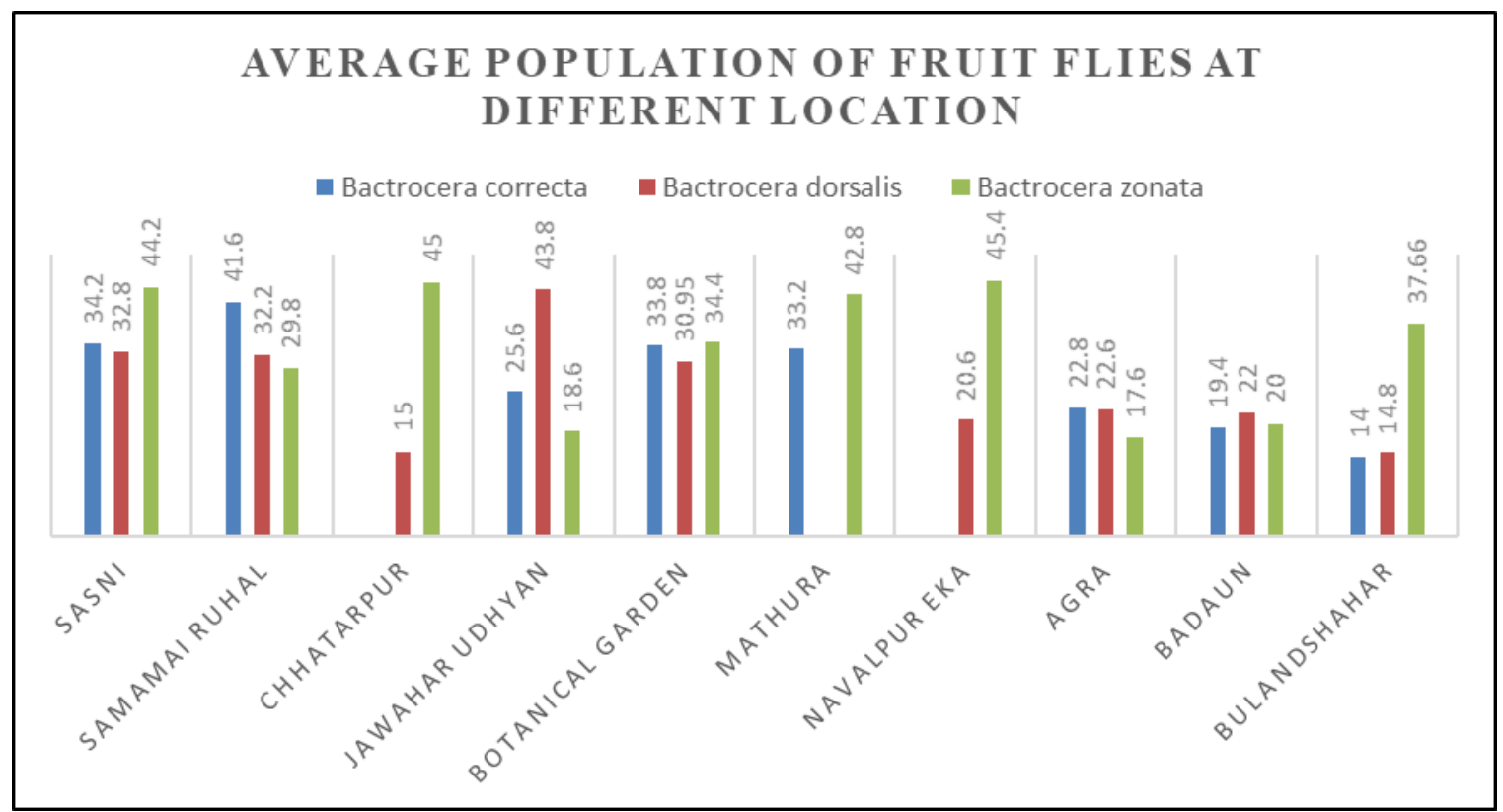

As a result of present studies fruit fly complex comprising species of $B$. correcta, B. dorsalis, and $B$. zonata, was recorded as of common occurrence in most of the guava growing areas of western Uttar Pradesh (Table 1, Fig.1). The present findings with regard to the species complex of fruit flies are in agreement with the observations made by Kadam, U.K., (2012). The author recorded B. dorsalis, $B$. caryeae, $B$. correcta and $B$. zonata in methyl eugenol traps. Verghese and Jayanthi (2001) recorded the species of $B$. dorsalis and $B$. correcta infesting guava in Bangalore. Madhura and Viraktamath (2003) recorded five species of fruit flies, viz., $B$. dorsalis, $B$. correcta, $B$. verbascifoliae, $B$. affinis and $B$. zonata at Bangalore. Kawashita et al., (2004) recorded $B$. correcta, $B$. dorsalis and $B$. zonata. Dale and Patel (2010) recorded $B$. dorsalis and $B$. zonata from Gujarat. $B$. correcta, B. dorsalis, and B. zonata complex was also reported from Ahmednagar district of Maharashtra from methyl eugenol lure traps and also from fruits of guava (Ukey et al., 2013). Kumar et al., (2018) recorded four species, viz., $B$. correcta, $B$. diversa, $B$. dorsalis and $B$. zonata from mango orchards from Meerut and Saharanpur areas of western
Uttar Pradesh from methyl eugenol traps. Along with this complex few other species of Bactrocera have been recorded primarily from guava and mango and some other fruits from various regions of the country (Madhura and Verghese, 2003; Satarkar et al., 2006; Deepa et al., 2009; Deepa et al., 2010; Haseeb et al., 2010; Galande and Ukey, 2011, Nair et al., 2018). As reported in the present findings, these species were reared from infested guava fruits by earlier workers also (Kapoor, 1993; Jalaluddin et al., 1999; Gupta and Bhatia, 2000; Jalaluddin, et al., 2001; Khan et al., 2005; Haseeb, 2007; Ukey et al., 2013).

However, the proportionate population of these species varied as caught in methyl eugenol lure traps and as reared from infested guava at different places surveyed (Table-2) as also reported by earlier workers. Findings of present studies revealed the dominance of B. zonata as observed from the data recorded on the emergence of flies from infested fruits collected from most of the areas surveyed, ranging from $21.00-69.85 \%, 21.06-49.80 \%$ and $20.12 \%-43.65 \%$ for B. zonata, B. dorsalis and $B$. correcta, respectively. Haseeb et al., 
(2010) recorded B. zonata as dominant species from Aligarh region. Khan et al., (2005) recorded proportionately higher number of B. zonata flies $(49.62 \%)$ on guava. Jalaluddin et al., $(1999,2001)$ recorded $B$. correcta as dominant species. Mandal et al., (2015) recorded $B$. correcta as dominant species on guava from Baruipur region in West Bengal contributing 90 per cent yield loss. Ukey et al., (2013) observed B. dorsalis $(49.95 \%)$ to be dominant species followed by B. zonata $(31.36 \%)$ and B. correcta $(19.95 \%)$ of the total number of emerged flies as studied in Ahmednagar, Maharashtra. According to Kapoor (2002) B. correcta, B. dorsalis and $B$. zonata species complex was reported as the most important fruit fly pest complexes in India. They are of common occurrence, widely distributed in guava growing regions throughout India and attack almost similar hosts, e.g. guava, mango, etc. while $B$. zonata also attack peaches. In the past two decades it has been observed that species, $B$. zonata has taken over $B$. dorsalis in the intensity of attack, number and host range as also indicated by the results of present findings.

In conclusion, fruit fly, Bactrocera spp. is the serious Problem in the guava fruit crop in Western Uttar Pradesh. Due to availability of host plants throughout the year their infestation is increasing day by day. Bactrocera spp. are infesting many host species throughout the entire geographical range. The knowledge of species complex, distribution and population abundance of fruit flies may help in devising management strategies in the region. As a result of survey and surveillance, three species of fruit flies, viz. B. correcta, B. dorsalis and B. zonata were found infesting guava in most of the guava growing areas of western Uttar Pradesh. However, B. zonata was found the most frequent and dominant species associated with guava in the region.

\section{Acknowledgments}

The authors are grateful to the Council of Science and Technology, Uttar Pradesh, Lucknow for providing financial assistance to carry out this study under the project, "Incidence and management of fruit flies, Bactrocera spp., in guava ecosystem in Western Uttar Pradesh".

The authors are also thankful to Dr. D.K. Srivastava, Joint Director, CST UP for his timely help and support in dealing with matters related with the project.

The authors are highly thankful to Dr. Debjani Dey, In-Charge, Insect Identification Services, National Pusa Collection, Division of Entomology, IARI, New Delhi for the help provided in the identification of fruit fly species. The authors are also grateful to Dean, Faculty of Agricultural Sciences and the Chairman, Department of Plant Protection, Aligarh Muslim University, Aligarh for necessary facilities provided for this study.

\section{References}

Allwood, A. J., Chinajariyawong, A., Kritsaneepaiboon, S., Drew, R. A. I., Hamacek, E. L., Hancock, D. L., and Leong, C. T. S. 1999. Host plant records for fruit flies (Diptera: Tephritidae) in Southeast Asia. Raffles Bulletin of Zoology, 47(Supplement 7), 1-92.

Arora, P.K., Batra, R.C., Mehrotra, N.K. \& Thind, S.K. 1998. Screening of some promising guava varieties against fruit fly. In: Reddy, P.P., Krishna Kumar, N.K. \& Verghese, A. (Eds) Proceedings of the first National Symposium on Pest Management in Horticultural Crops: Environmental implications and thrusts 101-102. Association for Advancement of pest Management in Horticultural Ecosystem, Bangalore.

Dale, N. S. and Patel, R. K., (2010). Population 
dynamics of fruit flies (Bactrocera spp) on guava and its correlation with weather parameters, Current Biotica. 4 (2): 245248.

David, K. J., and Ramani, S. 2011. An illustrated key to fruit flies (Diptera: Tephritidae) from Peninsular India and the Andaman and Nicobar Islands. Zoo taxa, 3021, 1-31.

Deepa M, and Agarwal, N. 2010. Studies on population dynamics of fruit flies of Bactrocera dorsalis complex. Indian Journal of Entomology, 72: 382-384.

Deepa, M., Neeraja Agarwal, Rahul Viswakarma, Kiran Kumari and Mithali K. L., 2009. Monitoring and weather parameters on Bactrocera complex through methyl eugenol traps. Annals of Plant Protection Sciences., 17 (2): pp. 332-336.

Dhillon, M. K., Singh, R., Naresh, J. S., and Sharma, H. C. 2005. The melon fruit fly, Bactrocera cucurbitae: a review of its biology and management. Journal of Insect Science, 5(1), 40.

Drew, R. A. I., and Raghu, S. 2002. The fruit fly fauna (Diptera: Tephritidae: Dacinae) of the rainforest habitat of the Western Ghats, India. Raffles Bulletin of Zoology, 50(2), 327-352.

Drew, R. A. I., Romig, M. C., and Dorji, C. 2007. Records of Dacinae fruit flies and new species of Dacus (Diptera: Tephritidae) in Bhutan. The Raffles Bulletin of Zoology, 55: 1-21.

Drew, R. A., and Romig, M. C. 2013. Tropical Fruit Flies (Tephritidae Dacinae) of SouthEast Asia: Indomalaya to North-West Australasia. CABI.

Galande, S. M. and Ukey, N.S. 2011. Fruit fly, Bactrocera species composition in Pune region of Maharashtra state. Journal of Applied Zoological Research, 22 (1): 1-4.

Gupta D and Bhatia R. 2000. Population fluctuations of fruit flies, Bactrocera spp. in sub mountainous mango and guava orchards. Journal of Applied Horticulture 2 (1): 47-9.

Gupta, J. N. and Verma, A. N., 1978. Screening of different cucurbit crops for the attack of the melon fruit fly, Dacus cucurbitae Coq. (Diptera: Tephritidae). Haryana Journal of Horticulture Sciences., 7: 78 - 82.
Haseeb, M. 2007. Current status of insect pest problem in guava. Acta Horticulture. 735: 453-468.

Haseeb, M., Varshne, D., Qamar, M., and Sharma, D. K. 2010. Biology and morphometries of Bactrocera zonata on guava. Annals of Plant Protection Sciences, 18: 508-510.

http://nhb.gov.in/statistics/Publication/Horticultur e\%20At\%20a\%20Glance\%202017\%20for $\% 20$ net\%20uplod\%20(2).pdf.

Jalaluddin, S. M., Natarajan, K. and Sadakathulla, S., 2001. Population fluctuation of the guava fruit fly, Bactrocera correcta (Bezzi) in relation to hosts and abiotic factors. Journal of Experimental Zoology. 4: 323327.

Jalaluddin, S.M. Natarajan, K., Sadakathulla, S. and Balasubramaniyan, S. 1999. Discovery of the guava fruit fly Bactrocera correcta (Bezzi). Entomon. 24: 195-196.

Kadam, U. K., 2012. Studies on species diversity, population dynamics and management of fruit flies in guava (Psidium guajava L.). $\mathrm{Ph}$. D thesis, Mahatma Phule Krishi Vidyapeeth, Rahuri-413 722, dist. Ahmednagar, Maharashtra, India 1-160 pp.

Kapoor, V. C. 2002. Fruit-fly pests and their present status. Proceedings of $6^{\text {th }}$ International Symposium, 6-10 May, 2002, Stellenbosch, South Africa, pp.23-33.

Kapoor, V. C. 2005. Taxonomy and biology of economically important fruit flies of India. Israel Journal of Entomology, 35-36: 459.

Kapoor, V. C. 2006. Taxonomy and biology of economically important fruit flies of India. Israel Journal of Entomology, 35:459-475.

Kapoor, V.C., (1993). Indian fruit flies (Insecta: Diptera: Tephritidae), oxford and IHB publishing company, New Delhi.

Kawashita, T., Rajapakse, G. B. J. P., and Tsuruta, K. 2004. Population surveys of Bactrocera fruit flies by lure trap in Sri Lanka. Research Bulletin of the Plant Protection Service (Japan).

Khan, M. A., Muhammad, A., Waseem, A. and Lee, L. L., 2005. Management of fruit flies of the most perishable fruit. Entomological Research. 35 (2): 79-84.

Kumar, P., Abubakar, Linda, A., Ketelaar, J.W. and Shanmugam, V. 2011. Fruit fly damage 
and crop losses. In: Field Exercise Guide on Fruit Flies Integrated Pest Management, Asian Fruit Fly IPM Project, Bangkok, Thailand, pp. 17.

Kumar, U., Prasad, C. S., Vaibhav, V. and Saran, S. 2018. Population dynamics of mango fruit fly species caught through methyl eugenol traps at different locations of Western plain zone of Uttar Pradesh. Journal of Pharmacognosy and Phytochemistry, 7: 2167-2168.

Liu, X., Jin, Y. and Ye, H. 2013. Recent spread and climatic ecological niche of the invasive guava fruit fly, Bactrocera correcta, in mainland China. Journal of pest science, 86: 449-458.

Madhura, H. S., and Viraktamath, C. A. 2003. Efficacy of different traps in attracting fruit flies (Diptera: Tephritidae). Pest Management In Horticultural Ecosystems, 9(2).

Mondal, C., Garain, P. K., Maitra, N. J. and Atit, M. 2015. Biofriendly management of guava fruit fly (Bactrocera correcta Bezzi) throygh wrapping technique. Journal. Applied and Natural Sciences, 7:358-363.

Nair, N., Bhattacharjee, T., Thangjam, B., Giri, U.and Debnath, M.R. 2018. Species diversity of Dacine fruit flies (Diptera: Tephritidae: Dacinae:Dacini) in Tripura, N. E. India. Journal of Entomology and Zoology Studies, 6 (1): 297-302.

nhb.gov.in/statistics/State Level/201718(1st\%20Adv.\%20Est).pdf

Rajitha, A. R. and Viraktamath, S. 2006. Monitoring fruit flies (Diptera: Tephritidae) in guava orchard in Dharwad, Karnataka. Karnataka Journal of Agricultural Sciences, 19: 35-39.

Satarkar, V.R., Krishnamurthy, S.V., Falerio, J.R., Verghese, A. and Stonehouse, J.M. 2006. An assessment of methyl eugenol dispensers and fruit fly species complex in orchard agro-ecosystems of Goa, India. Pest Management in Horticulture Ecosystems, 12(2): 161-163.

Ukey NS, Chandele AG, Wagh SS, Bansode GM 2013. Species composition of fruit flies, Bactrocera spp. (Diptera: Tephritidae) infesting guava in Maharashtra. Pest Management in Horticultural Ecosystems; 19(2):242-244.

Verghese, A., Madhura, H.S., Jayanthi, P.D.K. and Stonehouse, J.M. 2002. Fruit flies of economic significance in India, with special reference to Bactrocera dorsalis (Hendel). In: Proceedings of Sixth International Symposium of Fruit flies of Economic Importance, Stellenbosch, South Africa, pp. 317-324.

Verghese, A., Tandon, P. L., and Stonehouse, J. M. 2004. Economic evaluation of the integrated management of the oriental fruit fly Bactrocera dorsalis (Diptera: Tephritidae) in mango in India. Crop protection, 23(1), 61-63.

White, I. M., and Elson-Harris, M. M. 1992. Fruit flies of economic significance: their identification and bionomics. $\mathrm{CAB}$ International.

\section{How to cite this article:}

Irsad and Masarrat Haseeb. 2019. Species Complex of Fruit Flies, Bactrocera spp. (Diptera: Tephritidae) Infesting Guava in Western Uttar Pradesh. Int.J.Curr.Microbiol.App.Sci. 8(08): 2501-2510. doi: https://doi.org/10.20546/ijcmas.2019.808.291 